\title{
THE INFLUENCE OF WESTERN FLEET COMMAND'S MARITIME SECURITY OPERATION LEVEL AND THE DETERRENT STRATEGY TO THE EFFORT OF MANAGING THE EXTRA ORDINARY CRIME IN THE STRAIT OF MALACCA
}

\author{
Rapang Isak*, Postgraduate Student \\ Fanani Z., Widagdo Setyo, Domai Tjahjanulin, Postgraduate Lecturers \\ University of Brawijaya, Indonesia \\ *E-mail: ir.admiral4701@gmail.com
}

\begin{abstract}
The effort to tackle the criminal activities in the Strait of Malacca (SoM) which is implemented by The Western Fleet Command's maritime security operation (MSO) and its deterrent strategy. This research utilizes quantitative method with descriptive correlation data analysis. The study includes sampling of 76 persons from various establishments on the Western Fleet Command (such as ship's crew, staff ashore, air crew and naval bases' crew). This research discovers that there is a positive partial effect as high as $77,3 \%$ of the Western Fleet's MSO to the effort of managing the extra ordinary crime in the SoM with the level of relationship of 0,859 . This value has a strong category as it is associated with the interpretation of correlation coefficient. Similarly, there is a positive partial effect of $80,2 \%$ from the deterrent strategy with the level of relationship of 0,896 . This value has a very strong category as it is associated with the interpretation of correlation coefficient. There is also a positive partial effect of $83,8 \%$ of the Western Fleet's MSO to the deterrent strategy in the SoM with the level of relationship of 0,915 . This value has a strong category as it is associated with the interpretation of correlation coefficient. Finally, there is also a positive simultaneous effect of $81,1 \%$ of the Western Fleet's MSO and the deterrent strategy to the effort of managing the extra ordinary crime in the SoM with the level of relationship of 0,901 . This value has a very strong category as it is associated with the interpretation of correlation coefficient. The regression equation is obtained as $Y=-5,337+0,130 X_{1}+0,605 X_{2}$. Thus, with regard to optimize the effort to tackle the extra ordinary crime in the SoM, it is important that the Indonesian Navy (TNI AL) to enhance: personnel professionalism or competency; the standard of naval base capability to support the operation at sea; and legal awareness of the coastal community, especially those whose work at sea.
\end{abstract}

\section{KEY WORDS}

Maritime Security Operation (MSO), Deterrent Strategy, Extra Ordinary Crime in the Strait of Malacca (SoM).

The Malacca Strait is an international territorial water area between two mainland islands; those are Sumatra Island and Peninsular of Malaysia. Following the opinion of Bo Jiang (2014) that "Malacca Strait is one of the world's busiest shipping lanes, about $45 \%$ of total world trade carried by 70,000 merchant vessels over 300 gross tons of ply the South China Sea and about 20,000 oil tankers carrying one third of the world's crude oil passes through Malacca Strait annually ". For the people of Indonesia, the Straits of Malacca has strategic values in terms of economic, political and security. From the aspect of marine and fisheries resources, the Malacca Strait is one of the national fisheries sources where the territorial waters are in the RI-571 Fisheries Management Area which has a potential fishery resource of 276,000 tons/year which profitable for Indonesia as one of the national economic sources. In addition there are also vulnerabilities that can occur in these waters in the form of threats of maritime crime. Threats that can arise in the Malacca Strait are the threats to ships in the form of piracy, piracy safety, Illegal Unreported and Unregulated Fishing (IUU Fishing), illegal logging, people smuggling, pollution of the marine environment, goods and weapons which can be a threat to sovereignty and law in Indonesia's territorial waters. According to the International Maritime Bureau (IMB) it is said that piracy should be interpreted as: "the 
act of boarding any vessel with the intent to commit theft or any other crime and with the intent or capability to use force in the furtherance thereof" (Robert C Beckmean, 2002). In the period of 2011 to 2015, Indonesian waters and the Malacca Strait were waters that often involved piracy activities more than the surrounding waters in Southeast Asia. According to the International Maritime Bureau (IMB), it was shown that in 2007 there was an increase of pirate attacks by 10 percent in the waters of the Malacca Strait, especially tankers has been targeted for piracy (Paonganan., Zulkipli, Agustina, Kirana, 2012: 204). This form of piracy is a violation of the social and economic rights of the community.

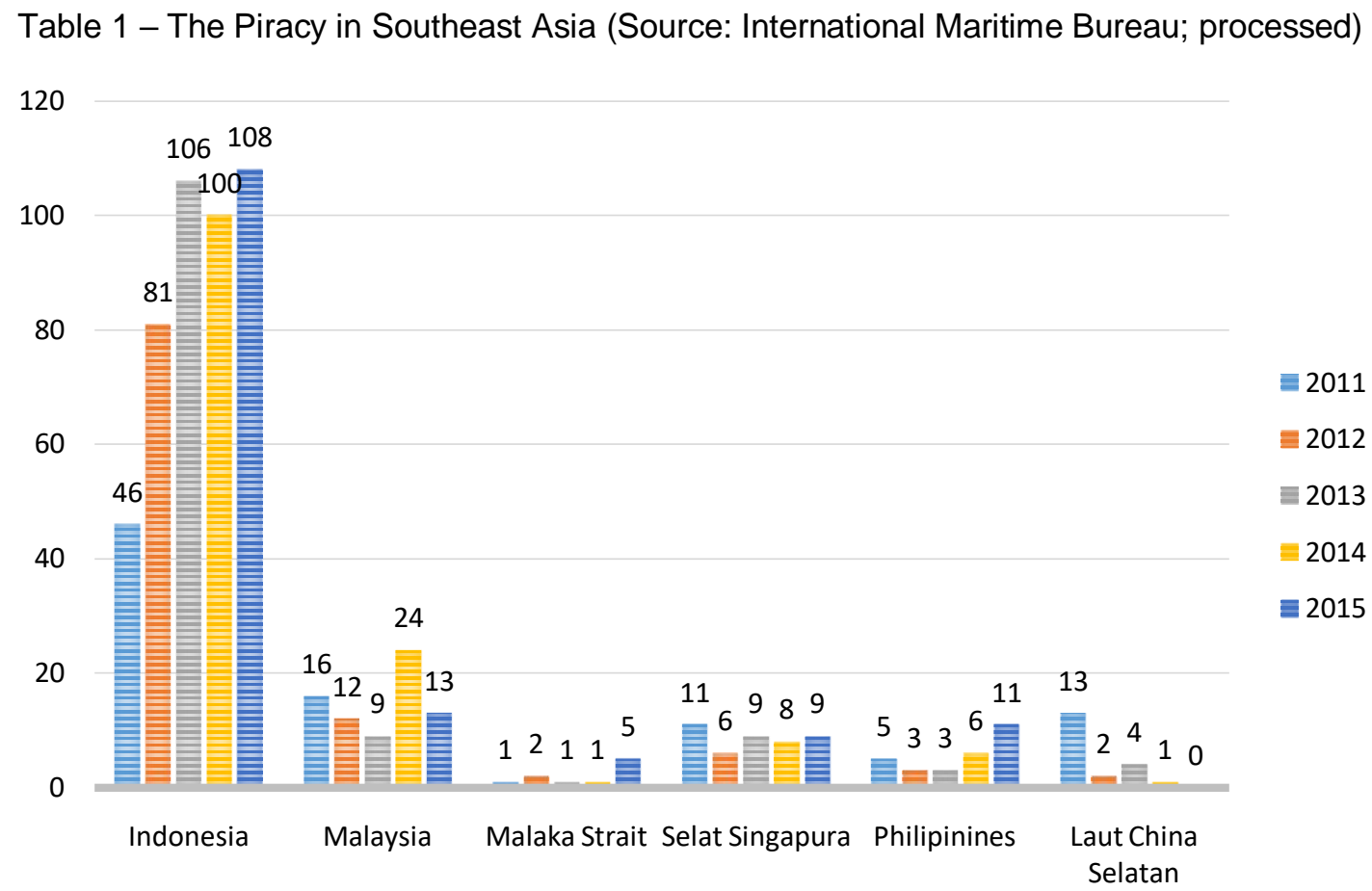

In addition to criminal acts of piracy, in the Malacca Strait there are still many criminal acts of IUU Fishing. The criminal acts of IUU Fishing are such as corruption (white collar crime) and smuggling which are categorized as extraordinary crime (The Director General Decree of PSDKP Number Kep 372 / DJ-PSDKP / 2011 of 29 December 2011 concerning the Technical Guidelines Fisheries Criminal Investigation). Based on the results of operations that is carried out by the Indonesian Navy in 2015 both in the western and eastern regions there were 28 Foreign Fish Vessels $(\mathrm{KIA})$ captured in western Indonesian waters and 23 Foreign Fish Vessels (KIA) captured in eastern Indonesian waters, where one area that is still rife with IUU Fishing in the waters of the Malacca Strait. As a result of the occurrence of IUU Fishing activities is the loss of effectiveness of fisheries management, loss of economic opportunities for fishermen and the occurrence of decreased food security (OECD, 2004: 49). Piracy and IUU Fishing is a form of certain crimes in the sea which is an extra ordinary crime. The Managing of piracy and IUU fishing activities in the waters of the Malacca Strait has not been able to be carried out optimally due to the limited facilities and infrastructure owned by law enforcement officials as well as not being integrated and synergizing each law enforcement agency at sea in carrying out their respective duties and authorities so that in the field overlapping still occurs in carrying out the task. Such conditions lead to the very high crime of piracy in the Malacca Strait so that these waters were once said as the most dangerous water in the world (Amarulla, 2012: 78).

Sea Power is a popular theory that introduced by several naval experts such as AT Mahan in his book "The Influence of Sea Power Upon History 1660-1763" suggests that there are 6 (six) main elements of sea power those are: Geographical Position, Physical Conformation, Extent of Territory, Number of Population, National Character, the 
Government (Mahan, 1889: 16-28). The Western Fleet Command (Koarmabar) which is currently the Fleet Command I (Fleet Command I) as a sea power force throughout 2015 has carried out law enforcement activities of sea and successfully carried out legal proceedings against 51 Foreign Fish Ships (KIA) which arrested in Indonesian waters, where the Strait Malacca is one area that is still rife with IUU Fishing. Security is needed in the Malacca Strait through the title of sea security operations and deterrence strategies, one of which is implemented by Fleet Command I. According to Corbet; the function of the Navy in achieving commands of the sea, one of which is securing maritime routes for trade. Another opinion by Geoffrey Till which quoted by Marsetio (2014: 41) states that sea power can be seen from two aspects, namely the input and output aspects. There are five things that can be achieved by the modern navy, namely sea control, expeditionary operations, inclusive good order at sea, stability operations, cooperative naval diplomacy (Geoffrey Till, 2009: 35). Fleet Command $\mathrm{I}$ is required to display excellent performance results, such as the maintenance of the security of the sea in all waters of the western region, especially the funnel of the Malacca Strait which is very important to the world economy. The Malacca Strait is an approaching funnel that is the responsibility of Fleet Command I and as a vocal point for security stability and economic improvement in the western region (Hendriawan, 2011: 7-8)

The Indonesian Navy as part of the Indonesian Army integral universally has three roles, those are the military, the police and the diplomacy role (Ken Booth in Marsetio, 2014: 39). The role of the police carried out by the Navy is carried out through the title of marine security operations by deploying the strength of the Navy that is incorporated in the Integrated Armed Weapon System (SSAT) consisting of KRI, Aircraft, Basecamp and Marines so as to prevent various illegal practices undertaken by certain parties both piracy and IUU Fishing can occur on or through the sea. In the implementation of marine security operations (OPSKAMLA) which is known the principles are independent or integrated operations, combat and non-combat operations, communication reliability, administration, morale and benefits (Kasal Decree Number 575 / IV / 2015 April 2, 2015 concerning implementation manuals marine security operations). Perspectives on maritime security have a broader scope depending on the type of threat. According to the US Naval Operation, states that in maritime security operations that concerning about the freedom of navigation, protection of trade and marine resources, also concerning the threats to the state in the form of theory, drug trafficking, and forms of transnational crime, piracy, environmental destruction and illegal immigration (Natalie et al., 2010: 5). Another opinion was expressed by Shicun Wu and Keyuan Zou (2009: 3) that maritime security, especially regarding safety of navigation, transnational crime actions including terrorism and sea piracy and prevention of conflicts and resolutions.

Maritime security is an issue that has attracted the attention of the international community in recent years. In various literature studies several experts expressed their views on the concept of maritime security. There is no clear definition of Maritime Security. This means that it can be varying depend on the user's context and perspective. In the military perspective, maritime security has traditionally focused on national security issues in terms of maintaining the integrity of the country's territory from various armed attacks or other uses of force and projecting the interests of other states (Klein., Mossop., Rothwell, 2010: 5). According to Christian Bueger, maritime security has a relationship with two important issues of a country such as security stability and economic development. This connection is achieved in four ways. First, the benefits of a country's sea area can only be realized in good maritime security. Second, sea borders are less visible and therefore a major source of conflict that can escalate into war between nations. Third, there are many perpetrators of crime that arise when the sea area is unstable. These perpetrators include inter-state crime organizations, human traffickers, sea slavery, piracy, and the smuggling of weapons and goods. Fourth, unstable sea areas cause losses related to state taxation (Christian Buerger, 2015). Understanding of the sea security which mentioned above is very important in order to create a comprehensive and integrative approach to managing it. One of the maritime security issues that has recently become a major concern of various countries is illegal activities at sea, one of which is piracy at sea. This activity has increased in scope, intensity 
and complexity, thereby threatening the social, economic and political conditions of a country and the surrounding region. In accordance with the conditions above, and developments occurring in the maritime world, there are two of the most important challenges in the maritime world, especially in Asia, namely guarantees for sea lanes in order to smooth the flow of goods and natural resources, avoidance of conflicts between countries in terms of competition or competition for trade and natural resources in the Region (Joshua Ho, 2004)

To be able to carry out the tasks of the Marine Security Operation of the Fleet Command I and the deterrence strategy by elements of the KRI and Aircraft in the ranks of The Fleet Command I required the ability, such the ability of personnel and the ability of defense equipment. Robbins and Timonthy A Judge (2014: 24) define that the ability "is an individual's current capacity to perform the various tasks in a job. Overall abilities are essentially made up of two sets of factors: intellectual and physical. " While Robert R. Katz in Moenir (http://www.landasanteori.com, accessed 28 April 2020) suggests 3 (three) types of basic abilities that must be possessed to support someone in carrying out a job or task that is Technical Skill, Human Skill and Conceptual Skill. In a military perspective, according to Sarkesian which quoted by Effendy Muhadjir (2011: 16) defines a professional military who will devote all his power and thoughts to carry out their duties in accordance with the role determined by the state in the military field, and really like his profession. Professional warriors can be achieved through education and training. In preparing KRI to carry out operational tasks, $\mathrm{KRI}$ readiness is needed. Ship technical readiness (KRI) is divided into two important parts, namely material platform readiness and supporting readiness (SkepKASAL No. SKEP / 1504 / V / 1991).

In another hand of going through the title of marine security operations, a deterrence strategy, it is needed to prevent the intentions of those who will interfere with the country's sovereignty and the territorial integrity of the Republic of Indonesia, and which will harm national interests through naval diplomacy and presence in the sea (Seskoal Instruction Package, 2015: 27) . To provide a deterrent impact on pirates and IUU Fishing in the Malacca Strait, the application of strict legal sanctions will reduce the occurrence of law violations at sea in the waters of the Malacca Strait. Piracy and IUU Fishing is an extra ordinary crime at sea that has recently attracted the attention of the government, the public and legal observers. Quoting on Jimly Asshiddiqi's opinion, law enforcement is the process by which efforts to uphold or function of legal norms are evident as guidelines for behavior in traffic or legal relations in public and state life (http://www.jimly.com, accessed on 27 April 2020). While Joseph Goldstein in Shant Dellyana (1988: 32) distinguishes criminal law enforcement into 3 parts, there are total enforcement, full enforcement and actual enforcement. According to the pompe in Monang Siahaan (2014:3) that criminal law can be described as whole legal regulations that indicate which actions should be subject to crime and where it should be. In law enforcement which influenced by legal factors, law enforcement factors, supporting facilities or factors, community factors and cultural factors (Soejono Soekanto, 2004: 42). In this research, the operational definition of a marine security operation title is the title of the Indonesian Navy (KRI, Aircraft, Basecamp and Marine Forces) force in upholding the law and sovereignty of the country on or through the sea. The operational definition of a deterrence strategy is a strategy for deploying the Navy's force through maritime security operations and developing the strength and capability of the Navy so as to have a deterrence effect. While the operational definition of Managing extra ordinary crime at sea is an effort to enforce the law against each criminal offender to uphold justice in society.

\section{METHODS OF RESEARCH}

The method used is quantitative descriptive correlation design. Components in this research method are population and sample, data collection techniques, research instruments, and data analysis techniques (Sugiyono, 2011: 62). Data collection techniques in this study used a survey method with a closed questionnaire. The objectives to be achieved in this study are; first, to analyze the positive effect of the level of marine security 
operation Fleet Command I on Managing extra ordinary crime at sea in the Malacca Strait. Second, Analyze the positive influence of the title of marine security operation Fleet Command I on the deterrence strategy in the Malacca Strait. Third, Analyze the positive influence of Fleet Command I sea security operation degree on Managing extra ordinary crime at sea in the Malacca Strait. Fourth, Analyze the direct positive effect of the title of Fleet Command I sea security operations and the deterrence strategy on Managing extra ordinary crime at sea in the Malacca Strait.

The population in this study were soldiers with officers' ranks serving in the organization Fleet Command I (Operations Staff, Intelligence Staff, Legal Services, Fleet Command Sea Combat Cluster I, Fleet Command I Sea Safety Cluster, KRI which consisted of eskorta ships, patrol ships and speedboat units), Lantamal I Belawan (Operations and Satkamla Staff) and 400 Tanjung Pinang Air Wing. The total population is 319 officers. In this study the sampling technique is used by Nonprobability sampling with a purposive sampling method, the technique of determining the sample with certain considerations (Bambang, 2015: 85). At the error level of $10 \%$ or the level of confidence of $90 \%$ using the Slovin formula obtained a sample of 75 people. Primary data obtained through questionnaires to capture the perception of all Navy officers according to the object of research through the Likert interval scale. Secondary data is generally in the form of evidence, historical records or reports that have been arranged in published and unpublished archives. The data processing is carried out through data coding, data tabulation, data analysis plans and scoring. Data was tested through validity testing using Product Moment Correlation contained in SPSS software version 25 for windows on the basis of decision making if the $r_{\text {count }}$ value is greater than the $r_{\text {table }}$ value then the questionnaire is declared valid, If the $r$ count value is smaller than the $r_{\text {table }}$ value then the questionnaire is declared invalid and dropped. Then the Reliability test will be carried out using Cronbach's Alpha technique using SPSS software version 25 for windows. In this study the criteria of an instrument are said to be reliable if the Cronbach Alpha or reliability coefficient ( $\mathrm{r} 11)>0.6$ (Sofyan Siregar, 2014: 57). In the framework of testing the hypothesis then carried out the classical assumption test, $t$ test and $f$ test. To find out the effect of the Fleet Command I Sea Security Operation Title and the Deterrence Strategy for Managing Extra Ordinary Crime at Sea in the Malacca Strait and the influence of the Fleet Command i Marine Security Operation Level on the deterrence strategy, a framework is needed as follows:

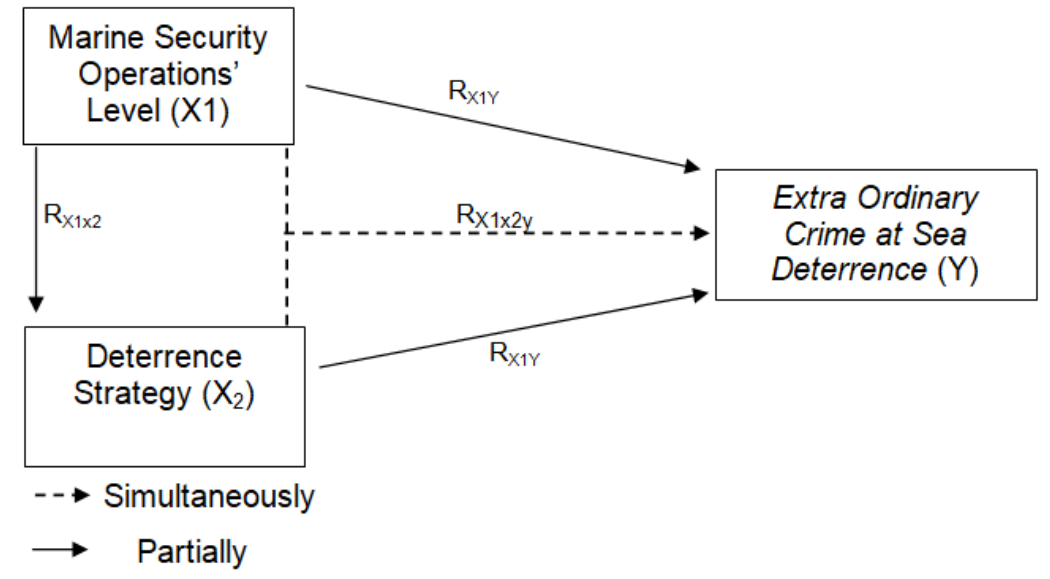

Figure 2 - Framework for Thinking (Source: Researcher Results, 2020)

\section{RESULTS AND DISCUSSION}

The level of Marine Security Operation Fleet I and the deterrence strategy implemented by Fleet Command I in Managing extra ordinary crime at sea in the Malacca Strait, in this case the crime of piracy and IUU Fishing had a significant impact, this can be seen in the results of the analysis conducted through Hypothesis testing as follows: 
Table 2 - Test Results of Variable Validity of Ocean Safety Operation Levels $\left(\mathrm{X}_{1}\right)$

\begin{tabular}{|c|c|c|c|}
\hline Questions & $R_{\text {count }}$ & $\mathrm{R}_{\text {table }}$ & Result \\
\hline$X_{1.1}$ & 0,475 & 0,226 & Valid \\
\hline$X_{1.2}$ & 0,560 & 0,226 & Valid \\
\hline$X_{1.3}$ & 0,300 & 0,226 & Valid \\
\hline$X_{1.4}$ & 0,562 & 0,226 & Valid \\
\hline$X_{1.5}$ & 0,722 & 0,226 & Valid \\
\hline$X_{1.6}$ & 0,802 & 0,226 & Valid \\
\hline$X_{1.7}$ & 0,454 & 0,226 & Valid \\
\hline$X_{1.8}$ & 0,527 & 0,226 & Valid \\
\hline$X_{1.9}$ & 0,726 & 0,226 & Valid \\
\hline$X_{1 \cdot 10}$ & 0,781 & 0,226 & Valid \\
\hline$X_{1.11}$ & 0,560 & 0,226 & Valid \\
\hline$X_{1.12}$ & 0,298 & 0,226 & Valid \\
\hline$X_{1.13}$ & 0,546 & 0,226 & Valid \\
\hline$X_{1.14}$ & 0,722 & 0,226 & Valid \\
\hline$X_{1.15}$ & 0,802 & 0,226 & Valid \\
\hline$X_{1.16}$ & 0,454 & 0,226 & Valid \\
\hline$X_{1.17}$ & 0,527 & 0,226 & Valid \\
\hline$X_{1.18}$ & 0,726 & 0,226 & Valid \\
\hline$X_{1.19}$ & 0,781 & 0,226 & Valid \\
\hline$X_{1.20}$ & 0,678 & 0,226 & Valid \\
\hline$X_{1.21}$ & 0,552 & 0,226 & Valid \\
\hline$X_{1.22}$ & 0,555 & 0,226 & Valid \\
\hline
\end{tabular}

Source: Researcher Results (2020).

From the table 2 output above, the calculated value is obtained. Then we compare this value with the value of $r_{\text {tabel }}$ (Riduawan, 2010: 372), $r_{\text {table }}$ can be seen in the Product Moment table with provisions $r_{(\alpha, n-2)}$ at the significance of $\alpha=0.05$ and $n=76$, then based on the $r$ Product table Moment obtained $r_{\text {table }}(0.05,74)$ of 0.226 . From the results of the analysis it can be seen that from items $X_{1.1}$ to $X_{1.22}$ the value of $r_{\text {count }}>r_{\text {table }}$ so that all items are valid and measurement instruments can be continued as material for data analysis.

Table 3 - Test Results Validity Variability Determination Strategy $\left(\mathrm{X}_{2}\right)$

\begin{tabular}{|c|c|c|c|}
\hline Questions & $\mathrm{R}_{\text {count }}$ & $\mathrm{R}_{\text {table }}$ & Result \\
\hline $\mathrm{X}_{2.1}$ & 0,497 & 0,226 & Valid \\
\hline $\mathrm{X}_{2 \cdot 2}$ & 0,514 & 0,226 & Valid \\
\hline $\mathrm{X}_{2 \cdot 3}$ & 0,734 & 0,226 & Valid \\
\hline $\mathrm{X}_{2 \cdot 4}$ & 0,514 & 0,226 & Valid \\
\hline $\mathrm{X}_{2 \cdot 5}$ & 0,734 & 0,226 & Valid \\
\hline $\mathrm{X}_{2 \cdot 6}$ & 0,783 & 0,226 & Valid \\
\hline $\mathrm{X}_{2 \cdot 7}$ & 0,382 & 0,226 & Valid \\
\hline $\mathrm{X}_{2 \cdot 8}$ & 0,626 & 0,226 & Valid \\
\hline $\mathrm{X}_{2 \cdot 9}$ & 0,515 & 0,226 & Valid \\
\hline $\mathrm{X}_{2 \cdot 10}$ & 0,702 & 0,226 & Valid \\
\hline $\mathrm{X}_{2 \cdot 11}$ & 0,780 & 0,226 & Valid \\
\hline $\mathrm{X}_{2 \cdot 12}$ & 0,446 & 0,226 & Valid \\
\hline $\mathrm{X}_{2 \cdot 13}$ & 0,286 & 0,226 & Valid \\
\hline $\mathrm{X}_{2 \cdot 14}$ & 0,436 & 0,226 & \\
\hline
\end{tabular}

Source: Researcher Results (2020).

From the output of table 3 above, the calculated value is obtained. Then we compare this value with the $r_{\text {table }}$ value, $r_{\text {table }}$ can be seen in the Product Moment table with the provisions of $r_{(\alpha, n-2)}$ at the significance of $\alpha=0.05$ and $n=76$, then based on the $r$ Product Moment table is obtained rtable $(0.05,74)$ amounting to 0.226 . From the results of the analysis it can be seen that from items $X_{2.1}$ to $X_{2.14}$ the value of $r_{\text {count }}>r_{\text {table }}$ so that all items are valid and the results of measurement instruments can be continued as material for data analysis. 
Table 4 - Test Results of Extra Ordinary Crime at Sea (Y) Variable Validity Test

\begin{tabular}{|c|c|c|c|}
\hline Questions & $\mathrm{R}_{\text {count }}$ & $\mathrm{R}_{\text {table }}$ & Result \\
\hline $\mathrm{Y}_{1}$ & 0,570 & 0,226 & Valid \\
\hline $\mathrm{Y}_{2}$ & 0,597 & 0,226 & Valid \\
\hline $\mathrm{Y}_{3}$ & 0,294 & 0,226 & Valid \\
\hline $\mathrm{Y}_{4}$ & 0,593 & 0,226 & Valid \\
\hline$Y_{5}$ & 0,714 & 0,226 & Valid \\
\hline$Y_{6}$ & 0,793 & 0,226 & Valid \\
\hline$Y_{7}$ & 0,449 & 0,226 & Valid \\
\hline$Y_{9}$ & 0,558 & 0,226 & Valid \\
\hline$Y_{10}$ & 0,721 & 0,226 & Valid \\
\hline
\end{tabular}

Source: Researcher Results (2020).

From the output of table 4 above, the $r_{\text {count }}$ value is obtained. Then we compare this value with the $r_{\text {table }}$ value, $r_{\text {table }}$ can be seen in the Product Moment table with the provisions $r_{(\alpha, n-2)}$ at the significance of $\alpha=0.05$ and $n=76$, then based on the $r$ Product Moment table is obtained $r_{\text {table }}(0.05,74)$ amounting to 0.226 . From the results of the analysis it can be seen that from items $Y_{1}$ to $Y_{10}$ the value of $r_{\text {coun }} t>r_{\text {table }}$ so that all items are valid, so the results of the measurement instrument can be continued as data analysis material.

The reliability test of this research data by using the Cronbach Alpha ( $\alpha$ ) technique or already contained in the SPSS 25.0 for windows program. Cronbach Alpha (a) can be used to test the reliability of instruments using a Likert scale of 1 to 5 . Variables are said to be reliable if each question gives a Cronbach Alpha value > 0.60 (Imam Ghozali, 2006: 46).

Table 5 - Reliability Test Results

\begin{tabular}{|l|l|l|l|}
\hline Research Variable & Cronbach's Alpha & N of Items & Conclusion \\
\hline Marine Security Operations Level $(\mathrm{X} 1)$ & 0,860 & 22 & Reliable \\
\hline Deterrence Strategy $\left(\mathrm{X}_{2}\right)$ & 0,754 & 14 & Reliable \\
\hline Extra Ordinary Crime At Sea Deterrence $(\mathrm{Y})$ & 0,817 & 10 & Reliable \\
\hline
\end{tabular}

Source: Researcher Results (2020).

Based on the output of table 5 above, the alpha cronbach's value on the research variable degree of Marine Security Operations Fleet Command I is 0.860 , the deterrence strategy variable is 0.754 and the extra ordinary crime at sea Managing variable in the Malacca Strait is 0.817 . This value is greater than 0.60 so that it can be concluded that the points of the measurement instruments of the research variables are declared reliable and the results of the measurement instruments can be continued as material for data analysis.

Table 6 - Normality Test Results

One-Sample Kolmogorov-Smirnov Test

\begin{tabular}{ll|r|}
\hline & & $\begin{array}{r}\text { Unstandardiz } \\
\text { ed Residual }\end{array}$ \\
\hline N & Mean & 76 \\
Mormal Parameters & Stb &, 0000000 \\
& Std. Deviation & 1,70850564 \\
& Absolute &, 095 \\
Test Statistic &, 095 \\
Asymp. Sig. (2-tailed) & Positive & -042 \\
a. Test distribution is Normal. &, 095 \\
b. Calculated from data. &, $088^{\circ}$ \\
c. Lilliefors Significance Correction.
\end{tabular}

Source: Researcher Results (2020). 
The classic assumption test is used to minimize the number of errors contained in the research data. Normality test is intended to determine whether the residuals under study are normally distributed or not. The criteria used is $\mathrm{HO}$ is accepted if Asymp. Sig (2-tailed)> from (a) 0.05 then the data in the test are normally distributed, while $\mathrm{HO}$ is rejected if Asymp. Sig (2tailed) < of $(\alpha) 0.05$ then the data that was tested was not normally distributed.

Based on the table 6 output above, it was obtained. Asymp Sig (2- tailed) of 0.088> ( $\alpha$ ) 0.05 so that the entire data is declared to have a normal distribution.

Autocorrelation testing is done to test whether in the linear regression model there is a correlation between the error of disturbance in period $t$ and error in $\mathrm{t} 1$ period (previous).

Table 7 - Autocorrelation Test Results

\begin{tabular}{|l|c|r|r|r|r|}
\multicolumn{7}{|c|}{ Model Summary $^{\mathrm{b}}$} \\
\hline Model & $\mathrm{R}$ & R Square & $\begin{array}{c}\text { Adjusted R } \\
\text { Square }\end{array}$ & $\begin{array}{c}\text { Std. Error of } \\
\text { the Estimate }\end{array}$ & $\begin{array}{c}\text { Durbin- } \\
\text { Watson }\end{array}$ \\
\hline 1 &, $901^{\text {a }}$ &, 811 &, 806 & 1,732 & 2,240 \\
\hline
\end{tabular}
a. Predictors: (Constant), Strategi Penangkalan, Gelar Opskamlabar
b. Dependent Variable: Penanganan Extra Ordinary Crime At Sea

Source: Researcher Results (2020).

Based on the output of table 7 above the Durbin Watson (DW) value of 2.240 if this value is compared to the table value at $5 \%$ significance with the number of samples $n=76$ and the number of independent variables $2(\mathrm{~K}=2)=2.74$ (look for the Durbin Watson table) the $\mathrm{dU}$ value is 1.678 and the $\mathrm{dL}$ value is 1.567 . DW value $2,240>$ from the upper limit of $1,678 \mathrm{dU}$ and less than $(4-\mathrm{dU})$ that is $4-1,678=2,322$ so it can be concluded that there is no autocorrelation.

It is used to determine whether there is a correlation between one independent variable with another. A good regression model does not occur correlation between independent variables (does not occur multicollinearity).

Table 8 - Multicollinearity Test Results

\begin{tabular}{|c|c|c|c|c|c|c|c|c|}
\hline \multicolumn{9}{|c|}{ Coefficients $^{a}$} \\
\hline & & \multicolumn{2}{|c|}{ Unstandardized Coefficients } & $\begin{array}{l}\text { Standardized } \\
\text { Coefficients }\end{array}$ & \multirow[b]{2}{*}{$t$} & \multirow[b]{2}{*}{ Sig. } & \multicolumn{2}{|c|}{ Collinearity Statistics } \\
\hline \multicolumn{2}{|c|}{ Model } & B & Std. Error & Beta & & & Tolerance & VIF \\
\hline \multirow[t]{3}{*}{1} & (Constant) & $-5,337$ & 2,490 & & $-2,143$ &, 035 & & \\
\hline & Gelar Opskamlabar &, 130 &, 069 &, 238 & 1,885 &, 063 & 162 & 6,176 \\
\hline & Strategi Penangkalan & .605 & .113 & 678 & 5,366 & .000 & 162 & 6,176 \\
\hline
\end{tabular}

a. Dependent Variable: Penanganan Extra Ordinary Crime At Sea

Source: Researcher's Results (2020).

Based on the output of table 8 above, the Tolerance value on the independent variable (degree of Marine Safety Operation Fleet Command I and deterrence strategy) is 0.162 greater than 0.10 and the VIF value on the independent variable (degree of Marine Safety Operation Fleet Command I and deterrence strategy) is 6,176 more smaller than 10 . It can be concluded that there is no multicollinearity.

Heteroscedasticity testing is the residual variance that is not the same in all observations in the regression model. This test uses the Glejser method.

Based on the output of table 9 above, the Sig value of the Marine Safety Operation I $\left(X_{1}\right)$ degree variable is 1,000 and the Sig value of the deterrence strategy variable $\left(X_{2}\right)$ is 1,000 . Sig value on both of these variables is greater than 0.05 so it can be concluded that heteroscedasticity does not occur. 
Table 9 - Heteroscedasticity Test Results

Coefficients $^{\mathrm{a}}$

\begin{tabular}{|rl|r|r|r|r|r|}
\hline \multirow{2}{*}{ Model } & \multicolumn{2}{|c|}{ Unstandardized Coefficients } & $\begin{array}{c}\text { Standardized } \\
\text { Coefficients }\end{array}$ & \multicolumn{2}{|c|}{} \\
\cline { 3 - 5 } & \multicolumn{1}{|c|}{$\mathrm{B}$} & \multicolumn{1}{|c|}{ Std. Error } & \multicolumn{1}{c|}{ Beta } & \multicolumn{1}{c|}{ Sig. } \\
\hline 1 & (Constant) & $5,142 \mathrm{E}-16$ & 2,490 & &, 000 & 1,000 \\
& Gelar Opskamlabar &, 000 &, 069 &, 000 &, 000 & 1,000 \\
& Strategi Penangkalan &, 000 &, 113 &, 000 &, 000 & 1,000 \\
\hline
\end{tabular}

a. Dependent Variable: ABSUt

Source: Researcher's Results (2020).

Linearity testing is used to determine the linearity of data, i.e. whether two variables have a linear relationship or not significance level of $5 \%(0.05)$. Two variables are said to have a linear relationship if the significance (deviation for linearity) is more than 0.05 .

Table 10 - Results of Extra Ordinary Managing Linearity Test Variables Crime At Sea $(Y)$ Based on Variable Degree of Sea Safety Operation Fleet Command I $\left(\mathrm{X}_{1}\right)$

\begin{tabular}{|c|c|c|c|c|c|c|c|}
\hline \multicolumn{8}{|c|}{ ANOVA Table } \\
\hline & & & $\begin{array}{c}\text { Sum of } \\
\text { Squares }\end{array}$ & $d f$ & Mean Square & $\mathrm{F}$ & Sig. \\
\hline \multirow{5}{*}{$\begin{array}{l}\text { Penanganan Extra } \\
\text { Ordinary Crime At Sea * } \\
\text { Gelar Opskamlabar }\end{array}$} & \multirow[t]{3}{*}{ Between Groups } & (Combined) & 947,510 & 29 & 32,673 & 7,036 &, 000 \\
\hline & & Linearity & 855,833 & 1 & 855,833 & 184,313 &, 000 \\
\hline & & Deviation from Linearity & 91,677 & 28 & 3,274 &, 705 & 836 \\
\hline & \multicolumn{2}{|l|}{ Within Groups } & 213,595 & 46 & 4,643 & & \\
\hline & \multicolumn{2}{|l|}{ Total } & 1161,105 & 75 & & & \\
\hline
\end{tabular}

Source: Researcher's Results (2020).

Based on the output of table 10 above, the Significance value obtained from the Linearity of the variable Managing extra ordinary crime at sea $(Y)$ based on the degree of Operation Sea Safety Fleet Command I $\left(X_{1}\right)=0.836>0.05$. It can be concluded that there is a linear relationship between the variables Managing extra ordinary crime at sea in the Strait of Malacca $(Y)$ based on the variable level of Marine Security Operation Fleet Command I $\left(\mathrm{X}_{1}\right)$.

Table 11 - Linearity Test Results for Extra Ordinary Managing Variables Crime At Sea $(\mathrm{Y})$ Based on Determination Strategy Variable $\left(\mathrm{X}_{2}\right)$

\begin{tabular}{|c|c|c|c|c|c|c|c|}
\hline \multicolumn{8}{|c|}{ ANOVA Table } \\
\hline & & & $\begin{array}{l}\text { Sum of } \\
\text { Squares }\end{array}$ & df & Mean Square & $\mathrm{F}$ & Sig. \\
\hline \multirow{5}{*}{$\begin{array}{l}\text { Penanganan Extra } \\
\text { Ordinary Crime At Sea * } \\
\text { Strategi Penangkalan }\end{array}$} & Between Groups & (Combined) & 1007,889 & 19 & 53,047 & 19,388 &, 000 \\
\hline & & Linearity & 931,520 & 1 & 931,520 & 340,466 &, 000 \\
\hline & & Deviation from Linearity & 76,368 & 18 & 4,243 & 1,551 &, 107 \\
\hline & Within Groups & & 153,217 & 56 & 2,736 & & \\
\hline & Total & & 1161,105 & 75 & & & \\
\hline
\end{tabular}

Based on the output of table 11 above, the Significance value of Deviation from Linearity is the Managing variable of extraordinary crime at sea $(\mathrm{Y})$ based on the variable of deterrence strategy $\left(X_{2}\right)=0.107>0.05$. It can be concluded that there is a linear relationship between the variables Managing extra ordinary crime at sea in the Malacca Strait $(Y)$ based on the variable deterrence strategy $\left(\mathrm{X}_{2}\right)$.

Partial Influence Analysis of Marine Security Operations Title Fleet Command I $\left(X^{1}\right)$ Against Managing Extra Ordinary Crime At Sea (Y). In the output table 12 below, the value of $t$ arithmetic on the title of Sea Safety Operation Fleet Command I is 14.403. The value of $t_{\text {table }}$ at $95 \%$ confidence level or $(\alpha) 0.05$ with $(n-2)$ obtained $t_{\text {table }}$ value $(0.05,74)=1.665$ this 
means that the $t_{\text {count }}$ is $14.403>t_{\text {table }} 1.665$. So that $\mathrm{H} 0$ is rejected and $\mathrm{H} 1$ is accepted, it can be concluded that there is a partial effect between the title of Operation Sea Safety of Fleet Command I on Managing extra ordinary crime at sea in the Malacca Strait.

Table 12 - Test Results of T Degree of Marine Safety Operation Fleet Command I $\left(\mathrm{X}_{1}\right)$ Against Managing Extra Ordinary Crime At Sea $(Y)$

Coefficients $^{\mathrm{a}}$

\begin{tabular}{|c|c|c|c|c|c|c|}
\hline \multirow{2}{*}{\multicolumn{2}{|c|}{ Model }} & \multicolumn{2}{|c|}{ Unstandardized Coefficients } & $\begin{array}{c}\text { Standardized } \\
\text { Coefficients }\end{array}$ & \multirow[b]{2}{*}{$t$} & \multirow[b]{2}{*}{ Sig. } \\
\hline & & $B$ & Std. Error & Beta & & \\
\hline 1 & (Constant) & $-1,085$ & 2,769 & &,- 392 & .696 \\
\hline & Gelar Opskamlabar & 468 &, 033 & 859 & 14,403 &, 000 \\
\hline
\end{tabular}

a. Dependent Variable: Penanganan Extra Ordinary Crime At Sea

Source: Researcher's Results (2020).

To determine the effect of the Marine Security Operations I variable title Fleet Command I on Managing extra ordinary crime at sea can be seen in the coefficient of determination (R Square).

Table 13 - Coefficient of Determination (R Square) Degree of Sea Security Operation Fleet Command I $\left(X_{1}\right)$ Against Managing Extra Ordinary Crime At Sea $(Y)$

Model Summary

\begin{tabular}{|l|l|r|r|r|}
\hline Model & R & R Square & \multicolumn{1}{|c|}{$\begin{array}{c}\text { Adjusted R } \\
\text { Square }\end{array}$} & $\begin{array}{c}\text { Std. Error of } \\
\text { the Estimate }\end{array}$ \\
\hline 1 &, $859^{\mathrm{a}}$ &, 737 &, 734 & 2,031 \\
\hline
\end{tabular}

a. Predictors: (Constant), Gelar Opskamlabar

Source: Researcher's Results (2020).

Based on the output of table 13 above obtained $R$ Square value of 0.737 which shows that $73.7 \%$ Managing extra ordinary crime at sea in the Malacca Strait is strongly influenced by the title of Marine Safety Operation Fleet Command I while the remaining $26.3 \%$ is influenced by other factors not included in this research. $R$ square value of $73.7 \%$ indicates that the title of Marine Security Operations Fleet Command I has a positive effect (+) on the Managing of extra ordinary crime at sea in the Malacca Strait (the first hypothesis is met).

Table 14 - Interpretation of Correlation Coefficients

\begin{tabular}{|c|c|}
\hline Coefficient interval & Relationship Level \\
\hline $0,80-1,000$ & Very strong \\
\hline $0,60-0,799$ & Strong \\
\hline $0,40-0,599$ & Strong enough \\
\hline $0,20-0,399$ & Low \\
\hline $0,00-0,199$ & Very low \\
\hline
\end{tabular}

Source: Riduwan (2010).

To find out the degree of correlation or relationship between the Marine Security Operation level of Fleet Command I to the Managing of extra ordinary crime at sea in the Malacca Strait, then based on table 13 above the $R$ value of 0.859 . If the value of 0.859 is consulted on the interpretation of the correlation coefficient (see table 14), the relationship between the level of Marine Security Operation Fleet Command I to the Managing of extra ordinary crime at sea in the Malacca Strait is very strong.

Partial Influence Analysis of Deterrence Strategy $\left(X_{2}\right)$ on Managing Extra Ordinary Crime At Sea $(Y)$. In the output table 15 below, the calculated value of the deterrence strategy is 17,328 . The value of $t_{\text {table }}$ at $95 \%$ confidence level or $(\alpha) 0.05$ with $(n-2)$ obtained 
ttable value $(0.05,74)=1.665$ This means that tcount $17.332>t_{\text {table }} 1.665$. So that $H 0$ is rejected and $\mathrm{H} 1$ is accepted, it can be concluded that there is a partial effect between the deterrence strategies on Managing extra ordinary crime at sea in the Straits of Malacca.

Table 15 - Test Results Determination Strategy (X2) Against Managing

Extra Ordinary Crime At Sea $(\mathrm{Y})$

Coefficients $^{\mathrm{a}}$

\begin{tabular}{|c|c|c|c|c|c|c|}
\hline \multirow[b]{2}{*}{ Model } & & \multicolumn{2}{|c|}{ Unstandardized Coefficients } & $\begin{array}{c}\text { Standardized } \\
\text { Coefficients }\end{array}$ & \multirow[b]{2}{*}{$\mathrm{t}$} & \multirow[b]{2}{*}{ Sig. } \\
\hline & & $B$ & Std. Error & Beta & & \\
\hline & (Constant) & $-4,920$ & 2,523 & & $-1,950$ & .055 \\
\hline & Strategi Penangkalan &, 800 &, 046 & 896 & 17,328 &, 000 \\
\hline
\end{tabular}

a. Dependent Variable: Penanganan Extra Ordinary Crime At Sea

Source: Researcher's Results (2020).

The value of $R$ Square in the output table 16 below is 0.802 which shows that $80.2 \%$ of Managing extra ordinary crime at sea in the Malacca Strait is strongly influenced by deterrence strategies while the remaining $19.8 \%$ is influenced by other factors not included in this study. In addition, the R square value of $80.2 \%$ indicates that the deterrence strategy has a positive effect $(+)$ on the Managing of extra ordinary crime at sea in the Malacca Strait (the second hypothesis is met).

Table 16 - Determination Coefficient (R Square) Determination Strategy $(X)$ to handle Extra Ordinary Crime At sea $(Y)$

Model Summary
\begin{tabular}{|l|l|r|r|r|}
\hline Model & R & R Square & $\begin{array}{c}\text { Adjusted R } \\
\text { Square }\end{array}$ & $\begin{array}{c}\text { Std. Error of } \\
\text { the Estimate }\end{array}$ \\
\hline 1 &, $896^{\text {a }}$ &, 802 &, 800 & 1,761 \\
\hline
\end{tabular}

a. Predictors: (Constant), Strategi Penangkalan

Source: Researcher's Results (2020).

In the output of table 16 above, the $R$ value of 0.896 when consulted on the interpretation of the correlation coefficient (see table 14), the relationship between the deterrence strategy and the Managing of extra ordinary crime at sea in the Malacca Strait is very strong.

Analysis of Partial Influence of Operation Fleet Sea Safety Operation I $\left(X_{1}\right)$ Against Deterrence Strategy $\left(X_{2}\right)$. In the output table 17 below, the value of t count in the title of Sea Operations Safety Fleet Command $I$ is 19,571 . The value of $t_{\text {table }}$ at $95 \%$ confidence level or (a) 0.05 with $(n-2)$ obtained the value of $t_{\text {table }}(0.05,74)=1.665$ This means $t_{\text {count }} 19.571>t_{\text {table }}$ 1.665. So that $\mathrm{HO}$ is rejected and $\mathrm{H} 1$ is accepted, it can be concluded that there is a partial effect between the title of Operation Sea Safety of Fleet Command I on the deterrence strategy.

Table 17 - Test Results for Title of Sea Security Operations Fleet Command I (X1) Against Deterrence Strategy (X2)

Coefficients $^{a}$

\begin{tabular}{|c|c|c|c|c|c|c|}
\hline \multirow{2}{*}{\multicolumn{2}{|c|}{ Model }} & \multicolumn{2}{|c|}{ Unstandardized Coefficients } & \multirow{2}{*}{$\begin{array}{c}\text { Standardized } \\
\text { Coefficients } \\
\text { Beta }\end{array}$} & \multirow[b]{2}{*}{$\mathrm{t}$} & \multirow[b]{2}{*}{ Sig. } \\
\hline & & B & Std. Error & & & \\
\hline & (Constant) & 7,028 & 2,434 & & 2,887 &, 005 \\
\hline & Gelar Opskamlabar &, 559 & 029 & ,915 & 19,571 &, 000 \\
\hline
\end{tabular}

a. Dependent Variable: Strategi Penangkalan

Source: Researcher's Results (2020). 
In the output table 18 below, the $\mathrm{R}$ Square value of 0.838 shows that $83.8 \%$ of the deterrence strategy is strongly influenced by the title of Marine Safety Operation Fleet Command I while the remaining $16.2 \%$ is influenced by other factors not included in this study. The $\mathrm{R}$ square value of $83.8 \%$ indicates that the title of Sea Safety Operation Fleet Command I has a positive effect $(+)$ on the deterrence strategy (the third hypothesis is met).

Table 18 - Coefficient of Determination (R Square) Title of Sea Safety Operation Fleet Command I (X1) Against Deterrence Strategy (X2)

Model Summary
\begin{tabular}{|l|l|r|r|r|}
\hline Model & R & R Square & $\begin{array}{c}\text { Adjusted R } \\
\text { Square }\end{array}$ & $\begin{array}{c}\text { Std. Error of } \\
\text { the Estimate }\end{array}$ \\
\hline 1 &, $915^{\text {a }}$ &, 838 &, 836 & 1,786 \\
\hline
\end{tabular}

a. Predictors: (Constant), Gelar Opskamlabar

Source: Researcher Results (2020).

In the output of table 19 above, the $R$ value of 0.915 when consulted on the Interpretation of the correlation coefficient (see table 14), the relationship between the title of Marine Safety Operation Fleet Command I to the deterrence strategy in the Malacca Strait is very strong.

Simultaneous Influence Analysis of Marine Security Operation Operations of Fleet Command I $\left(X_{1}\right)$ and Deterrence Strategy (X2) Against Managing Extra Ordinary Crime at Sea $(Y)$. The $F$ test is known as the Concurrent Test or the Anova Test, which is a test to see how the influence of all the independent variables together on the dependent variable.

Table 19 - Test Results of F Title of Fleet Command Sea Safety Operation I (X1) and Deterrence Strategy (X2) Against Managing Extra Ordinary Crime At Sea (Y)

\begin{tabular}{|c|c|c|c|c|c|c|}
\hline \multicolumn{7}{|c|}{ ANOVA ${ }^{a}$} \\
\hline \multicolumn{2}{|c|}{ Model } & $\begin{array}{c}\text { Sum of } \\
\text { Squares }\end{array}$ & df & Mean Square & $\mathrm{F}$ & Sig. \\
\hline \multirow[t]{3}{*}{1} & Regression & 942,181 & 2 & 471,090 & 157,084 &, $000^{b}$ \\
\hline & Residual & 218,924 & 73 & 2,999 & & \\
\hline & Total & 1161,105 & 75 & & & \\
\hline
\end{tabular}

Source: Researcher's Results (2020).

$F$ test results in the output table 19 above obtained $F_{\text {count }}$ value of 157.084 . While Ftable can be found in the $F_{\text {table }}$ table with the provisions of $F_{\text {table }}=F(\alpha-k, d k)$ where $\alpha=0.05$, $\mathrm{k}=2, \mathrm{dk}=\mathrm{nk}-1=76-2-1=73$. Then based on table $\mathrm{F}$ is obtained Ftable $=\mathrm{F}(\alpha)(\mathrm{k}, \mathrm{dk})=\mathrm{F}$ $(0.05)(2.73)=2.73$. Value of $F_{\text {count }} 157,084>\mathrm{Ft} 2.73$ so that, $\mathrm{H} 0$ is rejected and $\mathrm{H} 1$ is accepted. So it can be concluded that in this study the title of Marine Safety Operation Fleet Command I and the joint deterrence strategy simultaneously influence the Managing of extra ordinary crime at sea in the Malacca Strait.

Table 20 - Results of Multiple Regression Analysis Degree of Marine Security Operations of Fleet Command I (X1) and Deterrence Strategies (X2) Against Managing Extra Ordinary Crime At Sea (Y)

Coefficients $^{a}$

\begin{tabular}{|c|c|c|c|c|c|c|}
\hline \multirow{2}{*}{\multicolumn{2}{|c|}{ Model }} & \multicolumn{2}{|c|}{ Unstandardized Coefficients } & \multirow{2}{*}{$\begin{array}{c}\text { Standardized } \\
\text { Coefficients } \\
\text { Beta } \\
\end{array}$} & \multirow[b]{2}{*}{$\mathrm{t}$} & \multirow[b]{2}{*}{ Sig. } \\
\hline & & $B$ & Std. Error & & & \\
\hline \multirow[t]{3}{*}{1} & (Constant) & $-5,337$ & 2,490 & & $-2,143$ &, 035 \\
\hline & Gelar Opskamlabar & 130 & 069 & 238 & 1,885 &, 063 \\
\hline & Strategi Penangkalan & 605 & 113 & 678 & 5,366 &, 000 \\
\hline
\end{tabular}

a. Dependent Variable: Penanganan Extra Ordinary Crime At Sea

Source: Researcher's Results (2020). 
In the output of table 20 above, the constant value $(\alpha)=-5,337$ and the value of the regression coefficient of the Marine Safety Operation Fleet Command I $\left(b_{1}\right)=0.130$ and the deterrence coefficient of deterrence strategy $(b 2)=0.605$. From the three values in table 20 , we get the multiple regression equation to predict the Managing of extra ordinary crime at sea in the Malacca Strait based on the title of Sea Safety Operation Fleet Command I and the deterrence strategy are: $\mathrm{Y}=-5.337+0.130 \mathrm{X}_{1}+0.605 \mathrm{X}_{2}$.

Table 21 - Coefficient of Determination (R Square) Degree of Marine Security Operations Fleet Command I (X1) and Deterrence Strategy $\left(\mathrm{X}_{2}\right)$ Against Extra Ordinary Managing Crime at sea $(\mathrm{Y})$

\begin{tabular}{|l|l|r|r|r|}
\hline Model Summary \\
\hline Model & $\mathrm{R}$ & $\mathrm{R}$ Square & $\begin{array}{c}\text { Adjusted R } \\
\text { Square }\end{array}$ & $\begin{array}{c}\text { Std. Error of } \\
\text { the Estimate }\end{array}$ \\
\hline 1 &, $901^{\mathrm{a}}$ &, 811 &, 806 & 1,732 \\
\hline
\end{tabular}
$\begin{aligned} & \text { a. Predictors: (Constant), Strategi Penangkalan, Gelar } \\
& \text { Opskamlabar }\end{aligned}$

Source: Researcher's Results (2020).

In the output of table 21 above, it is known that the $\mathrm{R}$ Square value of 0.811 shows that $81.1 \%$ of Managing extra ordinary crime at sea in the Malacca Strait is strongly influenced by the title of Marine Security Operation Fleet Command I and deterrence strategy while $18.9 \%$ is influenced by factors other than the title of Operation Fleet Command Sea Security I and deterrence strategies. Based on the output table 21 above the $\mathrm{R}$ Square value of $81.1 \%$ shows that the degree of Marine Security Operations Fleet Command I and the deterrence strategy has a positive effect $(+)$ on the Managing of extra ordinary crime at sea in the Malacca Strait (fourth hypothesis fulfilled). To find out the level of correlation or the relationship of deterrence strategies to Managing extra ordinary crime at sea in the Malacca Strait, then based on the output table 21 above the $R$ value of 0.901 . If the value of 0.901 is consulted on the interpretation of the correlation coefficient (see table 14), the relationship between the title of Sea Safety Operation Fleet Command I and the deterrence strategy against the Managing of extra ordinary crime at sea in the Malacca Strait is very strong.

Therefore, in the framework of Managing marine acts such as piracy, IUU fishing and other marine crimes categorized as extra ordinary crime at sea, the implementation of marine security operations carried out by Fleet Command I needs to be carried out in an integrated manner with the principle of togetherness with other marine security agencies so that they are able to carry out marine control. Integration of security efforts at sea, in essence is the integration of the use of all forces and potentials in efforts to realize, maintain and improve sea security effectively and efficiently without reducing agency authority. Marine security operations carried out by Fleet Command I are an inseparable part of the National Defense and Security efforts which are carried out based on a prosperity and security approach in harmony and balance. To optimize and synergize the pattern of degree of strength of marine security operations carried out by Fleet Command $I$ it is necessary to fulfill the minimum needs of KRI, KAL, Aircraft and Base in the ranks of Fleet Command I in carrying out security in the Indonesian National Jurisdiction region, then it can be implemented through:

- Implement the title of force in maritime security under one Command and Control (Kodal), so that there is no overlap in its implementation;

- Enhance the early detection capability of the Navy Base (Lanal) and the Indonesian Navy Observation Post (Posal), by completing the communication facilities and the addition of patrol vessels (KAL);

- Increasing maritime air patrol activities in all Indonesian waters in the work area of Fleet Command I;

- Establish a Command and Control Center at the Navy Base in the ranks of Fleet Command I to tackle piracy, piracy, IUU Fishing and other law violations at sea;

- Utilizing Monitoring, Controlling and Surveillance (MCS) and Vessel Monitoring System (VMS) facilities that are owned by the KRI and the Indonesian Navy Base; 
- Carry out cross-sector coordination with various related agencies related to security issues at sea so that similar patterns of thinking are achieved, patterns of attitude and patterns of action in carrying out the duties and authorities of each agency in law enforcement at sea;

- Carry out the placement of KRI and KAL in areas that are vulnerable to the operation sector effectively based on KRl's technical capabilities so as to secure sectors of marine security operations that are prone to acts of sea at sea so that sea control can be controlled through sea combat standby operations and day-to-day sea operations.

In the implementation of the deterrence strategy in order to eliminate the acts of acts of speech at sea in the form of IUU fishing, piracy and piracy as well as other criminal acts which are included in the extra ordinary crime at sea in the working area of Fleet Command I, the deterrence strategy is implemented to prevent the intentions of the parties to be disrupting the country's sovereignty and territorial integrity of the Unitary State of the Republic of Indonesia, and which will harm national interests through naval diplomacy, presence at sea especially in border areas that have the potential to become a source of conflict in the future, and to build the capabilities and strength of the Indonesian Navy. This deterrence strategy can be implemented through naval diplomacy, presence at sea and building the strength and capability of the Navy. The holding of the deterrence strategy through Navy diplomacy is carried out using the muhibah operation pattern in the form of visits to other countries, carrying out world peace operations (peace keeping operations). Naval diplomacy is a form of performance of the Navy which is designed so that it can demonstrate the strength capabilities of the Navy that can cause deterrence effects for other countries so that it will cancel its intention to carry out territorial violations by warships or government vessels or violations a law carried out by foreign vessels carrying out acts of theft of Indonesia's marine biological resources. The deterrence strategy through the presence of the sea is carried out with a pattern of naval presence through a flag exhibition or show of force with a naval combat operation and daily sea operations. The involvement of forces that can be used in the framework of the deterrence strategy involves the KRI and $\mathrm{KAL}$, aircraft, marines and Navy bases. In addition, it can also be by cooperating with the strengths of other maritime security agencies that have duties and authorities in law enforcement at sea that can be realized in joint operations so that there is synergy in carrying out law enforcement and state sovereignty at sea.

\section{CONCLUSION AND RECOMMENDATIONS}

Based on the results of research that has been done, it can be concluded that:

- There is a partial positive influence on the title of Marine Security Operation Fleet Command I on managing extra ordinary crime at sea in the Malacca Strait with a value of $73.7 \%$ while $26.3 \%$ is influenced by other factors not included in this study;

- There is a partial positive effect on the deterrence strategy on managing extra ordinary crime at sea in the Malacca Strait with a value of $80.2 \%$ while $19.8 \%$ is influenced by other factors not included in this study;

- There is a partial positive effect on the title of Marine Security Operation Fleet Command I to the deterrence strategy in the Malacca Strait by $83.8 \%$ while $16.2 \%$ is influenced by other factors not included in this study;

- There was a simultaneous positive influence on the title of Sea Safety Operation Fleet Command I and the deterrence strategy for managing extra ordinary crime at sea in the Malacca Strait with a value of $81.1 \%$ while $18.9 \%$ was influenced by other factors not included in this study. The multiple regression equation is obtained $\mathrm{Y}=-5.337+0.130 \mathrm{X}_{1}+0.605 \mathrm{X}_{2}$.

Based on research that has been done, the suggestions that can be recommended:

- The importance of increasing the ability of the field of law for Navy personnel serving in the $\mathrm{KRI}$ and in the audience through courses and education in order to understand in carrying out the duties of the Navy in the pursuit, capture and investigation at sea; 
- The importance of implementing an appropriate deterrence strategy in the title of Sea Security Operation Fleet Command I in the Malacca Strait through the operation of elements of the Indonesian Navy and in collaboration with other components of sea power;

- The importance of increasing the standardization of the Navy base in this case the Belawan Lantamal I and other Navy bases located around the waters of the Malacca Strait in order to provide logistical support for elements of the KRI title and aircraft in carrying out provisions at the base;

- The importance of increasing sea defense area empowerment activities and increasing legal awareness for people living in coastal areas who work as fishermen and people who have a working environment at sea.

\section{REFERENCES}

1. Amarulla, Octavian (2012). Militer and Globalisasi.UI Press-Jakarta.

2. Buerger, Christian. (2015). What is Maritime Security. Forthcoming in Marine Policy. Cardiff University, Wales UK.

3. Beckmean, Robert C. (2002). Combatting Piracy and Armed Robbery Against Ships in Shoutheast Asia: The Way Forward. Ocean Development and International Law.

4. Dellyana, Shant (1988). Konsep Penegakan Hukum. Liberty. Yogyakarta.

5. Effendy, Muhadjir (2011). Profesionalisme Militer: Profesionalisme TNI. Malang. UMM Press Till, Geoffrey. (2009). Sea Power: A Guide for the Twenty First Century. Second Edition. Routledge. New York.

6. Ghozali (2006). "Aplikasi Analisis Multivariate Dengan Program SPSS".Semarang: Badan Penerbit Undip.

7. Ho, Joshua. (2004). The Shifting of Maritime Power and The Implication for Maritime Security in East Asia. Institute of Defence and Strategic Studies Singapore.

8. Hendriawan. (2011).Peringatan Hari Armada. Majalah Jalasena. Edisi No.08, 2011.

9. http://www.landasanteori.com/2015/10/pengertian kemampuan menurut ahli.html, diakses tanggal 28 April 2020, http://www.jimly.com, diakses 27 April 2020.

10. Jiang, Bo (2014).Maritime Piracy In Malacca Strait and South China Sea: Testing The Deterrence And Reactance Model. University of Maryland.

11. Klein, Mossop, and Rothwell, R. (2010). Maritime Security International Law and Policy Perspectives from Australia and New Zealand. Routledge Published.New York

12. Keputusan Kasal Nomor 575/IV/2015 Tanggal 2 April 2015 tentang buku petunjuk pelaksanaan operasi keamanan laut (PUM 5.110).

13. Keputusan Dirjen PSDKP Nomor Kep 372/DJ-PSDKP/2011 tanggal 29 Desember 2011 tentang Petunjuk Teknis Penyidikan Tindak Pidana Perikanan, Jakarta

14. Mahan, A.T. (1889). The Influence of Sea Power Upon history 1660-1783, NY.

15. Marsetio (2014).Sea Power Indonesia. Universitas Pertahanan. Jakarta.

16. OECD. Fish Piracy Combating Illegal, Unreported and Unregulated Fishing. Paris, 2004

17. Paket Instruksi Seskoal (2015). Strategi Pertahanan Laut Nusantara. Seskoal,Jakarta.

18. Robbin, Stephen P., Judge,Timothy A.(2014). Essentials of Organization Bahavior. Twelfth Edition, Pearson Education, Inc.

19. Reynolds C.G. Command of the Sea: The History and Strategy of maritime Empires.

20. Riduwan (2010). Metode and Teknik Menyusun Tesis. Bandung. Alfa Beta.

21. Soekanto, Soejono (2004). Faktor-Faktor Yang Mempengaruhi Penegakan Hukum. Cetakan kelima.Raja Grafindo Persada. Jakarta.

22. Sugiyono. (2011). Metode Penelitian Kuantitatif, Kualitatif, R and D. CV Alfabeta.

23. Suharjo, Bambang (2015). Statistika Terapan, Surabaya.

24. Siregar, (2014). Metode Penelitian Kuantitatif. Kencana Prenadamedia Group, Jakarta.

25. Siahaan, Monang (2014).Korupsi Penyakit Sosial Yang Mematikan. Jakarta.

26. Till (2009). Sea Power: A Guide for the 21st Century. Second Edition. Routledge. NY.

27. Wu, Shicun and Zou, Keyuan.(2009). Maritime Security in the South China Sea: Regional Implications and International Cooperation. Ashgate Publishing Limited. USA. 